\title{
Assessment of Heavy Metal and Pesticide Contamination in Banana Fields and Development of Phytoremediation System in Kozhikode District, Kerala, India
}

\author{
T. Arathi, K. P. Rahna, Delse P. Sebastian $\dagger$ and Satheesh George \\ Department of Botany, St. Joseph's College (Autonomous), Devagiri, Calicut, Kerala, India \\ $†$ Corresponding author: Delse P. Sebastian; delsbotany@ gmail.com
}

\section{Nat. Env. \& Poll. Tech.} Website: www.neptjournal.com

Received: 31-08-2020

Revised: $29-10-2020$

Accepted: 01-11-2020

Key Words:

Heavy metals

Banana fields

Ornamental plants

Lead phytoremediation

\begin{abstract}
Analysis of soil samples collected from various banana fields in Kozhikode district was carried out to identify the extent of heavy metal and pesticide contamination. Analysis by atomic absorption spectrometry revealed contamination of lead in some of the banana fields (Omasseri, Balussery, Vengeri \& Nanmanda) in the district. The Gas Chromatogram analysis revealed that the banana fields in Kozhikode district were free of organo-chloride and organo-phosphate pesticide contamination. Among the several ornamental plants evaluated for assessing lead phytoremediation potential, Dianthus chinensis L. showed the highest phytoaccumulation potential. Chrysanthemum indicum L., Ruellia simplex C. Wright and Lantana camara L.also showed high lead accumulation. Therefore, these

ornamental plants could be used in phytoremediation to remove lead from contaminated soils.
\end{abstract}

\section{INTRODUCTION}

Mining, processing, and smelting activities have contaminated soil and water resources with heavy metals at various places in the world. Act of geochemical weathering processes upon metallurgical wastes and by-products instigate the process of carrying heavy metals from contaminated places and redistributing them into soils, streams, and groundwater of surrounding areas (Fuge et al.1993, Paulson 1997). Thus, soil and water resources, the health of the ecosystems, and human populations are adversely affected by heavy metals. Many reports have shown that short-term or long-term exposure to toxic metals results in the reduction of microbial diversity and activities in soil (Kelly et al. 2003).

Heavy metals include arsenic (As), cadmium (Cd), chromium $(\mathrm{Cr})$, copper $(\mathrm{Cu})$, iron $(\mathrm{Fe})$, lead $(\mathrm{Pb})$, mercury $(\mathrm{Hg})$, platinum $(\mathrm{Pt})$, silver $(\mathrm{Ag})$, and the zinc $(\mathrm{Zn})$ group elements. Heavy metal concentrations beyond certain limits have adverse health effects because they interfere with the normal functioning of living systems. Lead poisoning causes inhibition of hemoglobin synthesis, problems in the functioning of kidneys, reproductive systems, cardiovascular system, and acute and chronic damage to the central nervous system (CNS) and peripheral nervous system (PNS). Mercury poisoning in its organic forms, like monomethyl and dimethylmercury, causes erethism (an abnormal irritation or sensitivity of an organ or body part to stimulation), acrodynia (also called Pink disease, which is characterized by rash and desquamation of the hands and feet), gingivitis, neurological disorders, stomatitis, total damage to the brain and CNS, and are also connected with a congenital malformation (Duruibe et al. 2007).

Contamination by xenobiotic chemicals has been reported in a large number of hazardous waste sites. Considering the increasing contamination of the environment, many remediation technologies have been developed to treat soil, water, and air contaminated by various pollutants, including in situ and ex situ methods (Aboulroos et al. 2006). Soil remediation is the return of soil to a condition of ecological stability together with the establishment of plant communities it supports or supported to conditions prior to disturbance. Conventional technologies for the removal of metals from polluted soils involve transportation of soil to laboratories, soil washing with chemicals to remove metals, and finally replacing the soil at its original location after disposing of its hazardous waste (Francis et al. 1999). This decontamination strategy is an ex situ approach and can be very expensive and damaging to the soil structure and ecology (Salt et al. 1998). Immobilization of heavy metals through the addition of lime (Krebs et al.1999), phosphate (Ebbs \& Kochian 1998), and calcium carbonate (Chen et al. 2000) has been suggested as remediation techniques. These remediation methods have the advantage of instantaneously reducing the risk factors arising from metal contamination, but these are considered 
temporary alternatives because the metals have not been fully removed from the soil environment. Conventional methods to remediate metal-contaminated soils like soil flushing, solidification/stabilization, vitrification, thermal desorption, encapsulation, etc. can be used at highly contaminated sites but these methods are not suitable for larger areas. Furthermore, these remediation techniques require high energy input and expensive machinery (Schnoor 1997). Conventional methods may destroy soil structure and decrease soil productivity (Leumann et al. 1995). Considering the problems associated with conventional methods, some organism-based remediation techniques, such as bioremediation was developed to degrade and detoxify certain contaminants. Compared to traditional methods, these biological systems are less amenable to environmental extremes but they are more cost-effective (Cunningham \& Berti 1993). Over the past decade, there has been increasing interest in the development of plant-based remediation technologies which have the potential to be low-cost, low-impact, and environmentally sound, a concept called phytoremediation (Cunningham \& Ow 1996).

Phytoremediation is applicable at sites containing organic, nutrient, or metal pollutants that can be absorbed by the roots of plants and sequestered, degraded, immobilized, or metabolized in place (Vijayan \& Sushama 2018). Phytoremediation is accepted because of its cost-effectiveness, aesthetic advantages, and long-term applicability (Yadav et al. 2010). To obtain the optimum remediation for the prevailing conditions, a particular contaminated site may require a combination of procedures. Biological, physical, and chemical methods may be used in combination with one another to reduce contamination to a safe and acceptable level. Considering all these, the present study was conducted to identify the extent of heavy metal and pesticide contamination and the development of a phytoremediation system in banana fields of Kozhikode District.

\section{MATERIALS AND METHODS}

\section{Study Area}

Kozhikode or Calicut district of Kerala state, India was selected as the study area for the present study. Bananas in their raw and value-added forms become an inseparable part of daily life and celebrations of the district.

\section{Soil Samples}

Soil samples collected from different banana fields of Kozhikode district were used for the study. Ten typical locations Omassery, Balussery, Kanthapuram, Vengeri, Vazhayur, Kakkur, Kuttiadi, Vanimel, Thiruvambadi, and Nanmanda were selected. In each of the selected banana field, soils were collected from a depth of $0-50 \mathrm{~cm}$.

\section{Plant Materials}

Ten common ornamental plants were chosen for the present study. Galphimia gracilis Bartl., Lantana camara L., Dahlia pinnata Cav., Chrysanthemum indicum L., Tithonia rotundifolia (Mill.) S.F.Blake, Ruellia simplex C.Wright, Dianthus chinensis L., Otacanthus caeruleus Lindl., Tecomaria capensis (Thunb.) Spach, and Catharanthus roseus (L.) G.Don .The plants were collected from Kozhikode district and acclimatized in the Botanical Garden of St. Joseph's college Devagiri.

\section{Glassware and Chemicals}

Beakers, distilled water, filter paper, funnels, grinder, heating mantle, measuring cylinders, oven, round bottom flasks, trays, weighing balance, Lead Acetate, Nitric acid $\left(\mathrm{HNO}_{3}\right)$, Perchloric acid $\left(\mathrm{HClO}_{4}\right)$, Hydrogen peroxide $\left(\mathrm{H}_{2} \mathrm{O}_{2}\right)$, Hydrochloric acid( $\mathrm{HCl})$, etc. were used for the present study. The chemicals used were obtained from HiMedia Laboratories Private Limited and Qualigen Chemicals, Mumbai, India.

\section{Experimental Protocol and Procedure}

Test for heavy metals: Soil samples collected from 10 different banana fields of Kozhikode district were used for the present study. One gram of each soil sample was digested with repeated addition of $10 \mathrm{ml}$ nitric acid $\left(\mathrm{HNO}_{3}\right)$ and $\mathrm{Hy}-$ drogen peroxide $\left(\mathrm{H}_{2} \mathrm{O}_{2}\right)$. The solutions were heated to boiling and filtered. $20 \mathrm{ml}$ of Hydrochloric acid $(\mathrm{HCl})$ was added to the initial digestate and the sample was refluxed. After filtration, the digestate was diluted to a final volume of 100 $\mathrm{mL}$. The heavy metal concentration in all the samples was analyzed by Flame Atomic Absorption Spectrophotometer at CWRDM (Centre for Water Resources Development and Management), Kozhikode, Kerala.

Test for pesticides: $5 \mathrm{~g}$ of each soil sample collected from different places of Kozhikode district were taken. It was then shaken with $20 \mathrm{ml}$ of hexane for one hour. After filtration, the volume of the solutions thus obtained was made to $50 \mathrm{ml}$ each. The Pesticide concentration in all the samples was tested by a Varian-make CP-3800 gas chromatograph equipped with Ni63 ECD electron-capture detector at CWRDM (Centre for Water Resources Development and Management), Kozhikode, Kerala.

Phytoremediation: For the phytoremediation study, ten common species of ornamental plants were selected. Twenty plants of each species were collected and acclimatized in the college garden for two weeks. These plants were divided 
into two sets. The first set of ten plants of each species was kept as the control plants. The second set of ten plants of each species was kept for Lead treatment. The heavy metal treatment was carried out for 10 days after the acclimatization period. Each plant of the control set was given $100 \mathrm{~mL}$ of water regularly for 10 days. Each plant of the second set was treated with $100 \mathrm{~mL}$ of lead solution regularly for 10 days. The lead solution was prepared by dissolving $10 \mathrm{~g}$ of lead in $10 \mathrm{~L}$ of water. After the treatment period, the plants were taken out of the soil, washed with distilled water to remove the soil particles, dried in an oven for 48 hours at $80^{\circ} \mathrm{C}$, and were ground into powder. $0.5 \mathrm{~g}$ ground powder of plants of each set were weighed accurately and digested with a $40 \mathrm{~mL}$ mixture of nitric acid $\left(\mathrm{HNO}_{3}\right)$ and perchloric acid $\left(\mathrm{HClO}_{4}\right)$ taken in the ratio of $4: 1$. The resulting mixtures were evaporated to dryness and were extracted with distilled water. The solutions were heated to boiling and filtered. The volume of the solutions thus obtained was made to $50 \mathrm{~mL}$ each. The metal ion concentrations in all the samples were analyzed by Flame Atomic Absorption Spectrophotometer at CWRDM (Centre for Water Resources Development and Management), Kozhikode, Kerala.

\section{RESULTS AND DISCUSSION}

\section{Soil Analysis}

The soil in agricultural areas may be contaminated by toxic heavy metals, pesticides, etc. The presence of such toxic substances may cause various health and environmental issues. Results obtained in the present study by the analysis of soil samples collected from various banana fields in Kozhikode district were summarised in Tables $1 \& 2$.

Table 1: Amount of $\mathrm{Pb}$ present in soil collected from banana fields of different places in Kozhikode District.

\begin{tabular}{|llll|}
\hline Serial No. & Fields & Pb Present in Soil $\left(\mathrm{mg}_{\mathrm{kg}}{ }^{-1}\right)$ & Hg Present in Soil $\left(\mathrm{mg} \cdot \mathrm{kg}^{-1}\right)$ \\
\hline 1 & Omassery & 0.02 & BDL \\
2 & Balussery & 0.07 & BDL \\
3 & Kanthapuram & BDL & BDL \\
4 & Vengeri & 0.19 & BDL \\
5 & Vazhayur & BDL & BDL \\
6 & Kakkur & BDL & BDL \\
7 & Kuttiadi & BDL & BDL \\
8 & Vanimel & BDL & BDL \\
9 & Thiruvambadi & BDL & BDL \\
10 & Nanmanda & 0.26 & BDL \\
\hline
\end{tabular}

BDL: Below Detection Level

Table 2: Amount of pesticides (Organochlorine \& Organophosphorus) present in soil collected from banana fields of different places in Kozhikode district.

\begin{tabular}{|c|c|c|c|}
\hline \multicolumn{2}{|c|}{ Organo phosphorus pesticides } & \multicolumn{2}{|c|}{ Organochlorine pesticides } \\
\hline Name of the pesticide & Concentration in soil & Name of the pesticide & Concentration in soil \\
\hline Mevinphos & BDL & Lindane & BDL \\
\hline Phorate & BDL & Aldrin & BDL \\
\hline Disulfoton & BDL & Daldrin & BDL \\
\hline Methyl parathion & BDL & $\alpha$-Endosulfan & BDL \\
\hline Thionazin & BDL & $\beta$-Endosulfan & BDL \\
\hline Parathion & BDL & DDE & BDL \\
\hline Triazophos & BDL & DDT & BDL \\
\hline Piperonyl butoxide & BDL & & \\
\hline Dimethoate & BDL & & \\
\hline Famphur & BDL & & \\
\hline $\mathrm{O}, \mathrm{O}, \mathrm{O}$ Triethyphosphorothioacetal & BDL & & \\
\hline Sulfotep & BDL & & \\
\hline
\end{tabular}

BDL: Below Detection Level 
The study revealed that in several places of Kozhikode district like Omassery, Balussery, Vengeri, and Nanmanda soil of banana fields was contaminated with lead. The amount of lead present was found to be $0.02 \mathrm{mg} . \mathrm{kg}^{-1}, 0.07 \mathrm{mg} . \mathrm{kg}^{-1}$, $0.19 \mathrm{mg} \cdot \mathrm{kg}^{-1}$ and $0.26 \mathrm{mg} \cdot \mathrm{kg}^{-1}$ respectively. In places like Kanthapuram, Vazhayur, Kakkur, Kuttiadi, Vanimel, and Thiruvambadi, soil in banana fields was devoid of lead pollution. Mercury contamination was not at all observed in the soil of banana fields of Kozhikode district.

The present study also revealed that organochlorine and organophosphate pesticide contamination was absent in soils of banana fields of various places in Kozhikode district. This may be due to increased awareness among farmers about the harmful effects of synthetic pesticides and also may be due to legal restrictions enforced by the Government of Kerala.

\section{Phytoremediation Studies}

Results of soil analysis revealed the presence of lead contamination in some of the banana fields in Kozhikode district. Hence phytoremediation studies were conducted to identify suitable ornamental plants that can be used for phytoremediation of lead in soil. Results observed in comparative analysis of the accumulation of lead-in-control and experimental plants are summarized in Fig. 1 and Table 3.

In control plants, the absorption level of lead was very low. This clearly showed that the concentration of lead in the soil used for the present study was very low. Among the various treated plants used for the study, the highest level of lead absorption was shown by $D$. chinensis L. (32.55 mg. $\left.\mathrm{kg}^{-1}\right)$, C. indicum L. (30.65 mg. $\left.\mathrm{kg}^{-1}\right)$, R. simplex C. Wright (23.11

Table 3: Phytoaccumulation levels of Lead-in-Control and Lead-treated Plants.

\begin{tabular}{|llll|}
\hline $\begin{array}{l}\text { Serial } \\
\text { No. }\end{array}$ & Plants & Lead accumulated in control plant $(\mathrm{mg} / \mathrm{kg})$ & Lead accumulated in treated plant $(\mathrm{mg} / \mathrm{kg})$ \\
\hline 1 & Galphimia gracilis Bartl. & BDL & 3.79 \\
2 & Lantana camara L. & 0.18 & 22.83 \\
3 & Dahlia pinnata Cav. & 0.07 & 4.43 \\
4 & Chrysanthemum indicum L. & 0.19 & 30.65 \\
5 & Tithonia rotundifolia (Mill.) S.F.Blake & 2.56 & 3.67 \\
6 & Ruellia simplex C.Wright & 0.60 & 23.11 \\
7 & Dianthus chinensis L. & 0.07 & 32.55 \\
8 & Otacanthus caeruleus Lindl. & 0.10 & 5.58 \\
9 & Tecomaria capensis (Thunb.) spach & 0.04 & 7.24 \\
10 & Catharanthus roseus (L.) G.Don & 2.25 & 3.01 \\
\hline
\end{tabular}

BDL-Below Detection Level

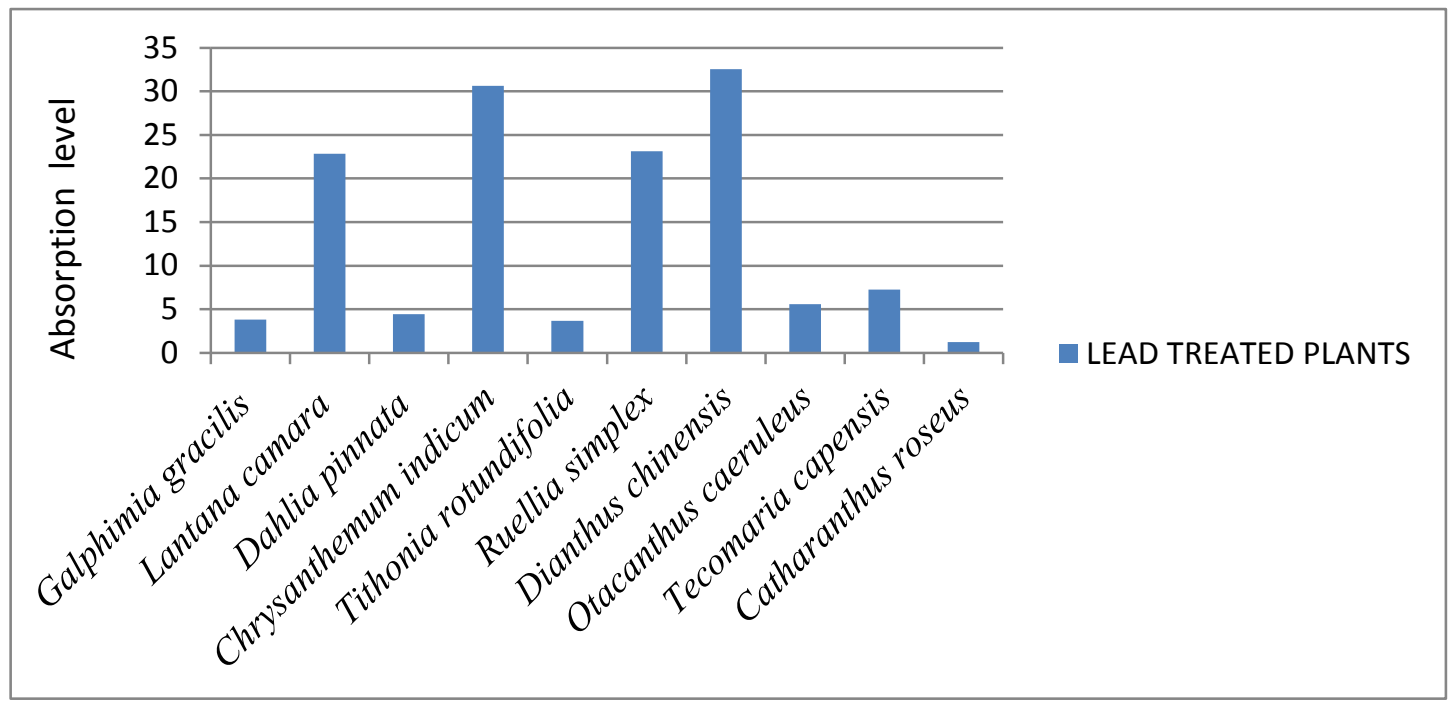

Fig. 1: Graph showing phytoaccumulation of lead by treated plants. 
mg.kg ${ }^{-1}$ ), and L. camara L. (22.83 mg. $\left.\mathrm{kg}^{-1}\right)$. Lead absorption of C. roseus (L.) G.Don (3.01 mg. $\mathrm{kg}^{-1}$ ) was found to be very low. Similar results showing a difference in lead absorption potential of different plant species were reported earlier by several workers (Ramana et al. 2008, Chirakkara \& Reddy 2015, Adesodun et al. 2010).

\section{Observations on Each Plant}

Galphimia gracilis Bartl: The concentration of lead-incontrol and lead-treated G. gracilis plants were BDL (Below Detectable Level) and $3.79 \mathrm{mg} / \mathrm{kg}$ respectively. Lead-treated G. gracilis plants showed yellowing of leaves within 10 days.

Lantana camara L.: The concentration of lead-in-control and lead-treated L. camara plants were $0.18 \mathrm{mg} / \mathrm{kg}$ and 22.83 $\mathrm{mg} / \mathrm{kg}$ respectively.

The treated L. camara plants accumulated a high amount of lead $(22.83 \mathrm{mg} / \mathrm{kg})$ in their plant body. Treated plants did not show any observable symptoms which indicated the high lead tolerance capacity of the $L$. camara plants.

Dahlia pinnata Cav.: The concentration of lead-in-control and lead-treated $D$. pinnata Cav. plants were $0.07 \mathrm{mg} / \mathrm{kg}$ and $4.43 \mathrm{mg} / \mathrm{kg}$ respectively.

White spots appeared on the leaves of treated $D$. pinnata Cav. plants within 10 days. Moreover, the leaves of treated plants were getting dried during the treatment, which showed that D. pinnata Cav plants cannot tolerate high lead content in the soil. Therefore in the present study, D. pinnata Cav plants were found to be less effective in the phytoremediation of lead-contaminated soil.

Chrysanthemum indicum L.: $C$. indicum L. plants showed accumulation of a high amount of lead. The concentration of lead-in-control and lead-treated plants of C. indicum L. plants were $0.19 \mathrm{mg} / \mathrm{kg}$ and $30.65 \mathrm{mg} / \mathrm{kg}$ respectively.

Lead-treated plants showed yellowing and drying of leaves within 10 days. Hence it was found that $C$. indicum L. plants cannot tolerate high lead content in the soil. Therefore $C$. indicum L. plants could not be used for phytoremediation of lead-contaminated soil.

Tithonia rotundifolia (Mill.) S.F.Blake: The concentration of lead-in-control and lead-treated T. rotundifolia (Mill.) S.F.Blake plants were $2.56 \mathrm{mg} / \mathrm{kg}$ and $3.67 \mathrm{mg} / \mathrm{kg}$ respectively. Plant showed only slight wilting during the treatment period. T. rotundifolia (Mill.) S.F.Blake plants were found to be less effective in the phytoremediation of lead-contaminated soil.

Ruellia simplex C.Wright: $R$. simplex C. Wright plants were found to be good accumulators of lead. The concentration of lead-in-control and lead-treated $R$. simplex $\mathrm{C}$. Wright were
$0.60 \mathrm{mg} / \mathrm{kg}$ and $23.11 \mathrm{mg} / \mathrm{kg}$ respectively. The $R$. simplex C. Wright plants showed only slight wilting during the treatment period.

Dianthus chinensis L.: Among the plants used for the study, D. chinensis L. plants showed the highest phyto accumulation potential.

The concentration of lead-in-control and lead-treated $D$. chinensis L. plants were $0.07 \mathrm{mg} / \mathrm{kg}$ and $32.55 \mathrm{mg} / \mathrm{kg}$ respectively. Slight wilting of the leaves of lead-treated $D$. chinensis L. plants was observed during the study.

Otacanthus caeruleus Lindl.: O. caeruleus Lindl. plants were found to be less effective in phytoremediation of lead in contaminated soil. The concentration of lead-in-control and lead-treated plants of $O$. caeruleus Lindl. were $0.10 \mathrm{mg} /$ $\mathrm{kg}$ and $5.58 \mathrm{mg} / \mathrm{kg}$ respectively. O. caeruleus Lindl. plants did not show any noticeable symptoms during treatment.

Tecomaria capensis (Thunb.)Spach: The concentration of lead-in-control and lead-treated plants of T. capensis (Thunb.) Spach were $0.04 \mathrm{mg} / \mathrm{kg}$ and $7.24 \mathrm{mg} / \mathrm{kg}$ respectively. $T$. capensis (Thunb.)Spach plants did not show any symptoms during treatment.

Catharanthus roseus (L.)G.Don: The concentration of lead-in-control and lead-treated plants of C. roseus (L.) G.Don were $2.25 \mathrm{mg} / \mathrm{kg}$ and $3.01 \mathrm{mg} / \mathrm{kg}$ respectively. Hence, the plant was found to be the least effective in lead phytoremediation of soil. In the present study C. roseus (L.) G.Don plants did not show any symptoms of lead toxicity during the treatment.

\section{CONCLUSIONS}

In the present study, D. chinensis L. showed the highest lead accumulating capacity. C. indicum $\mathrm{L}$., $R$. simplex $\mathrm{C}$. Wright, and $L$. camara L.also showed high lead accumulation. Hence the present study revealed that these ornamental plants could be used in phytoremediation to remove Lead from contaminated soils. Further studies are required to identify the concentration at which plants having phytoremediation potential shows the highest absorption. As the ornamental plants used for the present study were not edible, the risk of contaminants entering the food chain was reduced. Ornamental plants have the additional benefit of enhancing the aesthetics of the environment in addition to cleaning up the environment and generating additional income, including additional employment opportunities.

\section{ACKNOWLEDGEMENT}

The authors greatly acknowledge the Rusa, MHRD, Department of Higher Education, Government of India for the 
financial assistance for the purchasing of chemicals and other equipment needed for completing the work.

\section{REFERENCES}

Aboulroos, S.A., Helal, M.I.D. and Kamel, M.M. 2006. Remediation of Pb and $\mathrm{Cd}$ polluted soils using in situ immobilization and phytoextraction techniques. Int J. Soil Sediment Contam., 15(2): 199-215.

Adesodun, J.K., Atayese, M.O., Agbaje, T.A., Osadiaye, B.A., Mafe, O.F. and Soretire, A.A. 2010. Phytoremediation potentials of sunflowers ( $\mathrm{Ti}$ thonia diversifolia and Helianthus annuus) for metals in soils contaminated with zinc and lead nitrates. Water Air Soil Poll., 207 (1): 39-48.

Chen, H.M., Zeng, C.R., Tu, C. and Shen, Z.G. 2000. Chemical methods and phytoremediation of soil contaminated with heavy metals. Chemosphere, 41: 229-234.

Chirakkara, R.A. and Reddy, K.R. 2015. Plant Species Identification for phytoremediation of mixed contaminated soils. J. Hazard. Toxic Rad. Waste, 15: 128-129.

Cunningham, S.D. and Berti, W.R. 1993. Remediation of contaminated soils with green plants: An overview. In Vit ro Cell. Dev. Biol., 29P: 207-212.

Cunningham, S.D. and Ow, D.W.1996. Promises and prospects of phytoremediation. Plant Physiol., 110(3): 715.

Duruibe, J.O., Ogwuegbu, M. O. C. and Egwurugwu, J. N. 2007. Heavy metal pollution and human biotoxic effects. Int. J. Phy. Sci., 2(5): 112-118.

Ebbs, S.D. and Kochian, L.V. 1998. Phytoextraction of zinc by oat (Avina sativa), barley (Hordeum vulgare), and indian mustard (Brassica juncea). Environ. Sci. Technol., 32: 802-806.

Francis, C.W., Timpson, M.E. and Wilson, J.H. 1999. Bench- and pilot-scale studies relating to the removal of uranium from uranium-contaminated soils using carbonate and citrate lixiviants. J. Hazard. Mater., 66: 67-87.
Fuge, R., Pearce, F.M., Pearce, N.J.G. and Perkins, W.T. 1993. Geochemistry of $\mathrm{Cd}$ in the secondary environment near abandoned metalliferous mines. Wales. Appl. Geochem., Suppl. Iss., 2: 29-35.

Kelly, J. J., Häggblom, M. M. and Tate, R. L. 2003. Effects of heavy metal contamination and remediation on soil microbial communities in the vicinity of a zinc smelter as indicated by analysis of microbial community phospholipid fatty acid profiles. Bio. Fert. Soils, 38(2): 65-71.

Krebs, R., Gupta, S.K., Furrer, G. and Schulin, R. 1999. Gravel sludge as an immobilizing agent in soils contaminated by heavy metals: A field study. Water Air Soil Poll., 115: 465-479.

Leumann, C.D., Rammelt, R. and Gupta, S.K. 1995. Soil remediation by plants: Possibilities and limitations. (In German.) Agrarf Orschung (Switzerland), 2: 431-434.

Paulson, A.J. 1997. The transport and fate of Fe, Mn, Cu, Zn, Cd, Pb, and $\mathrm{SO} 4$ in a groundwater plume and in downstream surface water in the Coeur d'Alene mining district. Idaho, USA. Appl. Geochem., 12: 447-464.

Ramana, S., Biswas, A.K., Ajay and Rao, S. 2008. Phytoextraction of lead by marigold and chrysanthemum. Ind. J. Plant Physiol., 13(3): 297-299.

Salt, D.E., Smith, R.D. and Raskin, I. 1998. Phytoremediation. Plant Mol. Bio., 49: 643-668.

Schnoor, J. L. 1997. Phytoremediation: Technology Evaluation Report. Ground-Water Remediation Technologies Analysis Center, pp. 98-101.

Vijayan, V.D. and Sushama, P.K., 2018. Phytoremediation as an effective technology for the removal of heavy metals from dump yard soils. Nat. Env. Poll. Tech., 17(4): 1353-1358.

Yadav, R., Arora, P., Kumar, S. and Chaudhury, A. 2010. Perspectives for genetic engineering of poplars for enhanced phytoremediation abilities. Ecotoxicology, 19(8): 1574-1588. 